\title{
Performance Based Seismic Assessment of Masonry Infilled RCC Building with Diaphragm Discontinuity
}

\author{
G.S. Doiphode Vaibhav Dhandhukiya
}

\begin{abstract}
In multistoreyed RCC framed buildings, critical damages are due to seismic ground excitations, which cause catastrophic failuresat the weaker locations. Buildings with two types of structural irregularities namely diaphragm discontinuity and open ground story are considered. Assessment of seismic vulnerability of these buildings is done by using Nonlinear Static Pushover Analysis (NSPA). Performance Based Seismic Design of masonry infilled RCC buildings with two different shape of openings in the diaphragm is considered here with Design Basis Earthquake(DBE) and Maximum Considered Earthquake(MCE) where by selecting appropriate performance criteria in terms of Inter-story drift ratio(IDR) and Inelastic displacement demand ratio(IDDR) are critically observed. The Equivalent Linearization Procedure of Pushover analysis presented in FEMA 440, which is a modification of Capacity Spectrum Method based on ATC-40 guidelines, is performed in ETABS-2016 to study the performance of R.C.C. buildings with diaphragm discontinuity, designed as per IS-1893-2016.
\end{abstract}

Keywords: Diaphragm Discontinuity, Infill Walls, Performance Objectives, Pushover Analysis, RCC Buildings

\section{INTRODUCTION}

$\mathrm{D}_{\mathrm{i}}$ aphragm is a structural system which is used to transfer the major lateral loads to shear walls or frames primarily through in-plane shear mechanism. Openings in floor diaphragms reduces the in-plane rigidity of the diaphragm thus it affects the distribution of lateral loads to the load resisting elements, which eventually causes stress concentration near discontinued joints, which significantly changes the overall dynamic behaviour of the structure. As per IS-1893:2016, a diaphragm is said to have discontinuity in their in-plane stiffness, when the floor slabs have a cut-outs or openings of area more than 50 percent of the full area of the floor slab. Pushover analysis is an approximate analysis technique in which the building structure is subjected to

Revised Manuscript Received on December 25, 2020.

* Correspondence Author

Dr. G. S. Doiphode*, Applied Mechanics \& Structural Engineering Department, Faculty of Technology \& Engineering. The Maharaja Sayajirao University of Baroda, Vadodara, Gujarat-State, India. Email :gsdoiphode-appmech@msubaroda.ac.in

Vaibhav Dhndhukiya, PG Student, Applied Mechanics \& Structural Engineering Department, Faculty of Technology \& Engineering. The Maharaja Sayajirao University of Baroda, Vadodara, Gujarat-State, India. Email: vaibhav.dhandhukiya@gmail.com

(C) The Authors. Published by Blue Eyes Intelligence Engineering and Sciences Publication (BEIESP). This is an open access article under the CC BY-NC-ND license (http://creativecommons.org/licenses/by-nc-nd/4.0/) monotonically increasing lateral loads with an invariant height-wise distribution until a target displacement is reached or the structure becomes unstable. It also consists of a series of sequential elastic analysis, superimposed to approximate a force-displacement curve of the overall structure, which iscalled the capacity curve. The demand spectrum curve is normally estimated by reducing the standard elastic by $5 \%$ damped design spectrum by spectral reduction method. The intersection of the capacity curve and the demand spectra is referred to as the "Performance Point" of the structure as it forms the basis for assessing the performance of the structure by using certain explicit and quantifiable performance criterion. Pushover analysis procedure can be performed either under force-controlled or deformation-controlledmechanism [4]. In force-controlled pushover procedure, the full load combination is applied as specified in code only when the load is known (such as Gravity loading). In force-controlled pushover procedure some numerical error may affect the accuracy of overall results as target displacement may be associated with minor value of lateral stiffness which is developed due to mechanisms and P-delta effects. This method allows us to trace the sequence of yielding and failures of structural members along with their performance levels as well as the progress of the overall capacity curve of the structure.

The advantage of Performance Based Seismic Engineering (PBSE) is the possibility of achieving predictable seismic performance with uniform risk[8]. Performance based design begins with the selection of acceptability criteria stated in the form of one or more performance objectives. Each performance objective is essentially a statement of acceptable risk of incurring specific levels of damages i.e., structural and nonstructural due to which the consequent socio-economic losses that occur as a result of these damages, under a given seismic hazard level. The Global losses can be evaluated in the form of life-loss, direct economic costs or down-time (time for restoration) which is developed due to seismic damages. The procedure for estimating these losses is the central core crux of Performance Based Design (PBD) [8]. A series of structural simulations are performed and response of the building structure to loading is systematically worked out to estimate its probable behaviour under various possible design scenario events. If the performance of simulated model meets or exceeds the predefined performance objectives, the design is complete, or else the designed is revised in an iterative manner until the performance objectives are achieved.

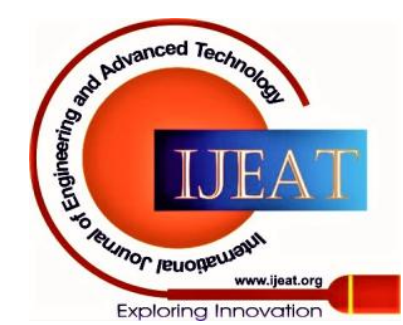


Fig.1 shows here the necessary diagrammatic presentation which highlights the basic procedure of PBD

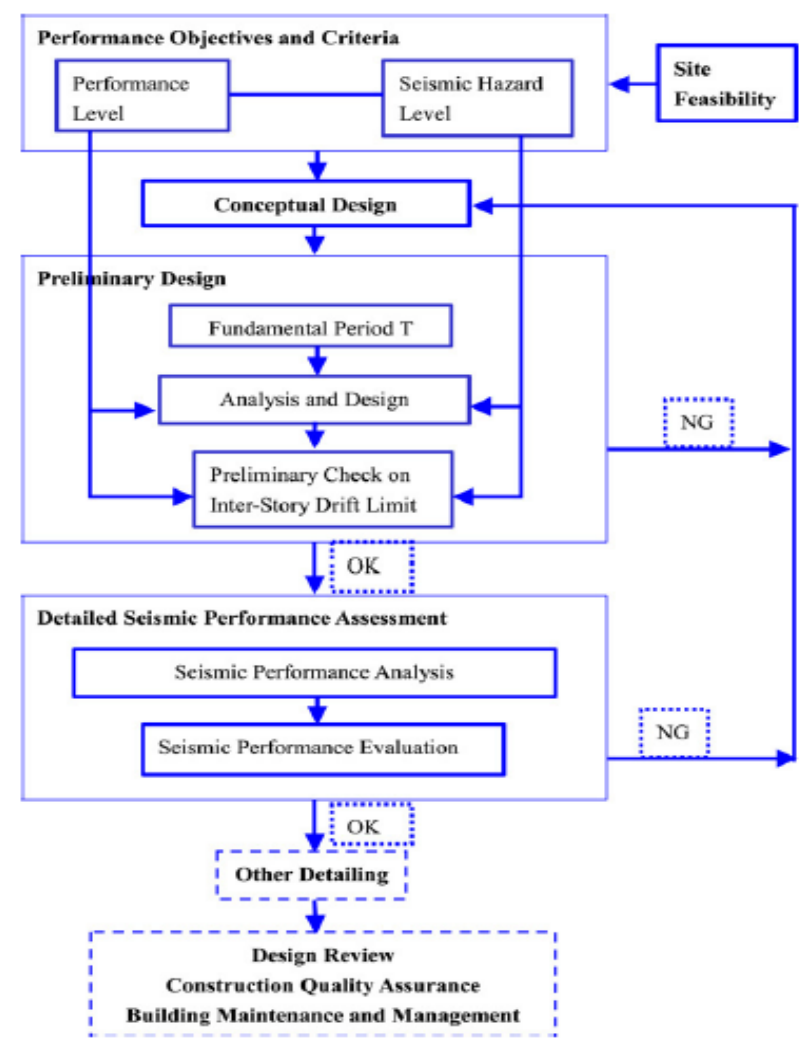

Fig. 1. Performed Based Designflow-chart for new buildings

Table - 1: Performance levels for a building

\begin{tabular}{|c|c|}
\hline $\begin{array}{c}\text { Performance } \\
\text { Level }\end{array}$ & Characteristics \\
\hline Operational & $\begin{array}{l}\text { Very light overall damage, no } \\
\text { permanent drift, structure } \\
\text { substantially retains original strength } \\
\text { and stiffness. Minor cracks are } \\
\text { visible. All important systems remain } \\
\text { functional. }\end{array}$ \\
\hline $\begin{array}{l}\text { Immediate } \\
\text { Occupancy }\end{array}$ & $\begin{array}{l}\text { Light overall damage, no permanent } \\
\text { drift, structure substantially retains } \\
\text { original strength and stiffness. Minor } \\
\text { cracks visible. Elevators can be } \\
\text { restarted. Fire protection operable. }\end{array}$ \\
\hline Life Safety & $\begin{array}{l}\text { Moderate overall damage, some } \\
\text { permanent drift, some residual } \\
\text { strength and stiffness left in all } \\
\text { stories. Gravity load bearing } \\
\text { elements function. Walls and } \\
\text { parapets remain in-plane. Damage to } \\
\text { partitions. Building may be beyond } \\
\text { economical repair. }\end{array}$ \\
\hline $\begin{array}{l}\text { Collapse } \\
\text { Prevention }\end{array}$ & $\begin{array}{l}\text { Severe overall damage, large } \\
\text { permanent drifts, little residual } \\
\text { strength and stiffness. Load bearing } \\
\text { columns and wall function. Infills } \\
\text { and unbraced parapets failed or at } \\
\text { incipient failure. Building is near } \\
\text { collapse. }\end{array}$ \\
\hline
\end{tabular}

The performance level can be assessed by using the displacement demand at the performance point. The adequacy of the structure can be checked by comparing the response parameters with the acceptable limits for various performance levels. Performance levels are associated with earthquake hazard and design levels.Each performance level is quantified by parameters associated with strength, stiffness and ductility respectively. Regarding the strength, OP (Operational level) corresponds to elastic behaviour. Over-strength must be ensured for other each performance levels and no strength degradation can occur beyond the ductility limit. No weak story exists and the structure has enough vertical capacity. Regarding ductility, the concept of Inelastic Displacement Demand Ratio(IDDR) [5] is employed. IDDR represents the ratio of inelastic displacement demand over the ultimate inelastic displacement capacity. Acceptable values of IDDR associated with structural system performance levels OP,IO,DC,LS and CP are 0,0.2,0.4,0.6 and 0.8, respectively.

Table-II: Allowable Inelastic Displacement Demand Ratio (IDDR)

\begin{tabular}{|c|c|c|c|c|c|}
\hline $\begin{array}{c}\text { Performance } \\
\text { Level }\end{array}$ & OP & IO & DC & LS & CP \\
\hline $\begin{array}{c}\text { IDDR } \\
\text { Value }\end{array}$ & 0 & 0.2 & 0.4 & 0.6 & 0.8 \\
\hline
\end{tabular}

Regarding stiffness, the maximum Inter-story Drift Ratio(IDR) is considered to limit building lateral displacement. In this research, based on references like FEMA 356[5], ATC 40[4], SEAOC blue book [7] and other literatures, the IDR limits in Table III are preliminarily suggested. Structural systems are mainly classified into four types namely, load-bearing walls, the frame systems, the moment resisting frames and the dual systems.

Table -III: Allowable Inter-Story Drift Ratio (IDR)

\begin{tabular}{|c|c|c|c|c|c|}
\hline \multirow{2}{*}{$\begin{array}{c}\text { Structural } \\
\text { system }\end{array}$} & \multicolumn{5}{|c|}{ Performance Level } \\
\cline { 2 - 6 } & OP & IO & DC & LS & CP \\
\hline $\begin{array}{c}\text { System with } \\
\text { masonry } \\
\text { shear walls }\end{array}$ & 0.005 & 0.007 & 0.007 & 0.007 & 0.009 \\
\hline $\begin{array}{c}\text { Other } \\
\text { Systems }\end{array}$ & 0.005 & 0.01 & 0.015 & 0.02 & 0.025 \\
\hline
\end{tabular}

\section{STRUCTURAL MODELLING}

The $(5 \times 5)$ bays moment resisting frame ( $\mathrm{G}+6$ floors) is modelled by using commercial code ETABS. Gravity loads comprising of Dead load (DL) and Live load (LL) for sections were applied to slab and beam elements. Initially, static linear analysis is performed by using only gravity loads by using appropriate reduction factor for live loads with the combining lateral loads applied to the frame as per IS:1893-2016 [1]. The influence of non-structural walls i.e., masonry infills damage mechanism and deformation capacity are considered for all the buildings.

\section{A. Masonry Modelling}

The infill walls are modelled using Multi-linear plastic link elements, which can be used for both the linear as well as non-linear static analysis.

Published By:

Blue Eyes Intelligence Engineering and Sciences Publication 
For linear analysis, the effective stiffness for the spring was calculated using the stiffness for equivalent compression diagonal strut, the dimensions of which can be calculated by using the equations given in IS:1893-2016. The width of strut is calculated from,

Where,

$$
W d s=0.175 * \alpha h^{-0.4} * L_{d s},(1)
$$

$\alpha h=h \operatorname{col}(\sqrt[4]{(E m * t * \sin 2 \theta) /(4 * E f * I c * h i n f)})$,

In which

, $\mathrm{h}_{\mathrm{col}}=$ height of column,

$\mathrm{E}_{\mathrm{m}}=$ Modulus of elasticity of masonry,

$\mathrm{L}_{\mathrm{ds}}=$ Length of diagonal strut

, $\mathrm{E}_{\mathrm{f}}=$ Modulus of elasticity of frame,

$\mathrm{I}_{\mathrm{c}}=$ M.O.I. of columns beside infill,

$\mathrm{h}_{\text {inf }}=$ height of infill,

$\mathrm{t}=\mathrm{t}_{\mathrm{w}}=$ thickness of strut $=$ thickness of infill wall.

$\mathrm{L}_{\mathrm{inf}}=$ Length of infilled wall

So, linear stiffness $=\mathrm{AE}_{\mathrm{m}} / \mathrm{L}_{\mathrm{ds}}$, with $\mathrm{A}=\mathrm{W}_{\mathrm{ds}} * \mathrm{t}$

For non-linear behaviour of infill wall, the force deformation curve is supplied for the multi-linear plastic link element. The force-deformation relationship is obtained from the equations given by Dolsek and Fajfar [09], which are mentioned below,

i. Initial stiffness:

$$
K e=\frac{G w * \operatorname{tw} * \operatorname{Linf}}{\operatorname{hinf}}
$$

ii. Maximum force:

$$
\begin{gathered}
F \max =0.818 * \text { ftp } * \text { Lw } * \text { tw } * B(2) \\
\text { Where B }=\left(1+\left(\mathrm{C}_{1}{ }^{2}+1\right)^{2}\right) / \mathrm{C}_{1} \text { with } \\
\mathrm{C}_{1}=1.925 * \operatorname{Linf} / \operatorname{hinf}
\end{gathered}
$$

iii. Cracking force and Residual force: $\mathrm{FCr}=0.6^{*} \mathrm{Fmax}$ and $\mathrm{Fr}=0.2^{*} \mathrm{Fmax}$

\section{iv. Deformations:}

Dcr $=$ Fcr $/ \mathrm{Ke}, \mathrm{Dm}=0.2 \%$ strain, Dult $=5 * \mathrm{Dm}$

Table IV shows the values of propertiesof the masonry wall are tabulated below

Table- IV: Masonry properties

\begin{tabular}{|c|c|}
\hline Infill wall length, $\mathrm{L}_{\mathrm{inf}}$ & $4150 \mathrm{~mm}$ \\
\hline Infill wall height, $\mathrm{h}_{\mathrm{w}}$ & $2650 \mathrm{~mm}$ \\
\hline Thickness, $\mathrm{t}_{\mathrm{w}}$ & $230 \mathrm{~mm}$ \\
\hline Mortar Strength, $\mathrm{f}_{\mathrm{mo}}$ & $5.7 \mathrm{Mpa}$ \\
\hline Masonry Strength, $\mathrm{f}_{\mathrm{m}}$ & $3.65 \mathrm{Mpa}$ \\
\hline Elastic modulus, $\mathrm{E}_{\mathrm{m}}$ & $2007.5 \mathrm{Mpa}$ \\
\hline Crushing Strength, $\mathrm{f}_{\mathrm{tp}}$ & $2.5 \mathrm{Mpa}$ \\
\hline Shear Modulus, $\mathrm{G}_{\mathrm{w}}$ & $836.45 \mathrm{Mpa}$ \\
\hline
\end{tabular}

Fig. 2 depicts the force-deformation curve for masonry infill wall modelling which is used for further calculation.

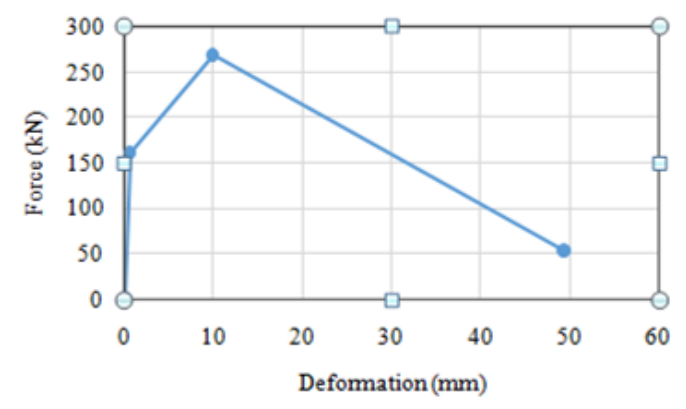

Fig. 2. Force-Deformation curve for Infilled wall

For performing pushover analysis on the space frame, three pushover load cases are to be defined. The first load case is 'Push Down' which applies Gravity Loads (force controlled case) and it is followed by two lateral load cases 'PUSH X' and 'PUSH Y'(displacement controlled cases) for each of the two orthogonal directions of the building respectively. The method of iteration used in the pushover analysis is the Newton-Raphson method. The Gravity load combination comprises of 'DL+0.25LL' and for the two lateral load, load patterns from equivalent static analyses ' $E Q$ $\mathrm{X}$ ' and 'EQ $\mathrm{Y}$ ' have been used to push the structure.

\section{B. Non-Linear Plastic Hinge}

Under seismic loads, plastic hinges are usually formed at the junctions of the beams and columns in the framed structures. For the beam elements, the plastic hinges are mostly caused due to uniaxial bending moments, whereas for the column elements, the plastic hinges are mostly developed due to the interaction between axial loads and biaxial bending moments. Hence, to account for material nonlinearity in the pushover analysis, different types of plastic hinges should be applied for beams and columns each.In ETABS, hinge properties can be assigned to the members using either user-defined or default hinge properties which are based on FEMA-356 and Asce-41 criteria. The default M3 hingesareapplied at both the ends of beams to simulate the plastic hinges caused by uniaxial moment, and the default P-M2-M3 hinges are applied at both the ends of columns to simulate the plastic hinges caused by axial loads and biaxial bending moments.

\section{Problem Statement}

Total 6 types of buildings are considered here to validate numerically the technical theme. It is necessary to know the influence of diaphragm discontinuity and masonry infills as non-structural elements on the non-linear response parameters, and based on those, performance based seismic assessment is carried out until the predefined performance criteria in terms of IDR and IDDR are satisfied. Model I representsregular building as bare frame, Model II represents building with central opening in "+" Shape in the diaphragm and Model III represents "E" Shaped building in Plan.Models IV, V and VI represent the same three buildings respectively incorporating the infill walls on external periphery. The prototype buildings are $\mathrm{G}+6$ reinforced concrete buildings consisting of five bays in both orthogonal directions.

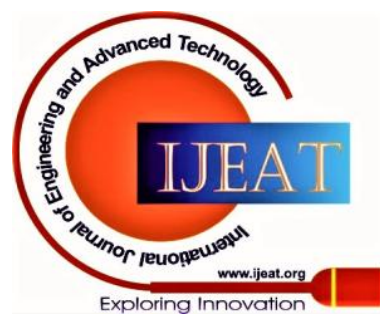


The spacing along $\mathrm{X}$ and $\mathrm{Y}$ directions is $4.5 \mathrm{~m}$ and the story height is $3 \mathrm{~m}$. Hence the overall plan dimension of the building is $22.5 \mathrm{~m} \times 22.5 \mathrm{~m}$. The primary beam dimension is taken as $230 \mathrm{~mm} \times 350 \mathrm{~mm}$, column size as $375 \mathrm{~mm} \times 375 \mathrm{~mm}$ (For Model I), 350mm x 350mm (For models II, III, IV, V and VI) with fixed support at base respectively. The slab thickness is considered to be $130 \mathrm{~mm}$ constant. To achieve the required performance objectives, sizes of beams and columns are increased until the performance meets or exceeds the predefined objectives. The building design data with plan and elevation details are shown below. Building frame with and without infilled also shown in Fig. 4 while Fig. 5 depicts rendered view of same building

Table- V: Building Design Data

\begin{tabular}{|c|c|}
\hline \multirow{2}{*}{ Live Load } & $3.0 \mathrm{kN} / \mathrm{m}^{2}$ on typical floor \\
\cline { 2 - 2 } & $1.5 \mathrm{kN} / \mathrm{m}^{2}$ on terrace \\
\hline Floor Finishing & $1.0 \mathrm{kN} / \mathrm{m}^{2}$ \\
\hline Terrace Finishing & $2.0 \mathrm{kN} / \mathrm{m}^{2}$ \\
\hline Water Proofing & $1.0 \mathrm{kN} / \mathrm{m}^{2}$ \\
\hline Wall Load & $\begin{array}{c}230 \mathrm{~mm} \text { thick masonry } \\
\text { walls only at the exterior } \\
\text { periphery }\end{array}$ \\
\hline Masonry wall density & $20 \mathrm{kN} / \mathrm{m}^{3}$ \\
\hline Design Seismic Load & As per IS:1893(Part 1$)$ \\
\hline Slab thickness & $130 \mathrm{~mm}$ \\
\hline Zone factor, Z & 0.24 \\
\hline Importance factor, I & 1 \\
\hline $\begin{array}{c}\text { Response reduction } \\
\text { factor, R }\end{array}$ & 5 \\
\hline Soil Type & $\begin{array}{c}\text { Type II, Medium as per } \\
\text { IS:1893 }\end{array}$ \\
\hline Concrete Grade & M30 \\
\hline Steel Grade & Fe 415 (HYSD Bars) \\
\hline
\end{tabular}

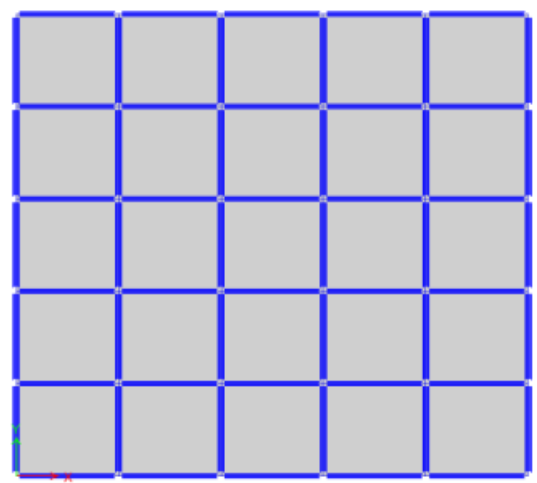

Fig. 3. Continuous Diaphragm ( Model 1)

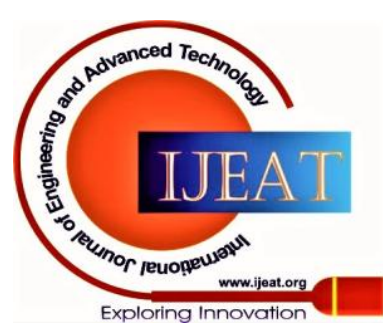




\section{RESULTS AND DISCUSSIONS}

The performance point of the complete building frame responds to the considered hazard level which is evaluated through the Capacity Spectrum Method by using Equivalent Linearization technique [4],[5]. The structure is laterally pushed again to the target displacement associated with the performance point to assess the behaviour of both the structural system and its resisting structural and non structural elements, if such a hazard level occurs.

Table - VI: System Performance Evaluation regarding IDR \& IDDR for Model 1

\begin{tabular}{|c|c|c|c|c|}
\hline Type & \multicolumn{4}{|c|}{$\begin{array}{c}\text { Regular Building-Bare } \\
\text { Frame }\end{array}$} \\
\hline $\begin{array}{l}\text { Performance } \\
\text { Obj. }\end{array}$ & \multicolumn{2}{|c|}{$\begin{array}{l}\text { Basic Safety } \\
\text { Obj. }\end{array}$} & \multicolumn{2}{|c|}{$\begin{array}{l}\text { Enhanced } \\
\text { Safety Obj. }\end{array}$} \\
\hline $\begin{array}{c}\text { Seismic } \\
\text { Hazard Level }\end{array}$ & DBE & MCE & $\mathrm{DBE}$ & MCE \\
\hline $\begin{array}{l}\text { Optimum } \\
\text { Section } \\
\text { dimensions } \\
\left(\mathrm{mm}^{*} \mathrm{~mm}\right)\end{array}$ & \multicolumn{2}{|c|}{$\begin{array}{c}\text { Col: } \\
(375 \times 375), \\
\text { Beam: } \\
(230 \times 350)\end{array}$} & \multicolumn{2}{|c|}{$\begin{array}{c}\text { Col: } \\
(400 \mathrm{X} 400), \\
\text { Beam: } \\
(230 \mathrm{X} 350) \\
\end{array}$} \\
\hline IDRa & 1.5 & 2.5 & 1 & 2 \\
\hline IDR (\%) & 1.03 & 1.876 & 0.994 & 1.753 \\
\hline $\begin{array}{l}\text { Check if } \\
\text { IDR } \leq \text { IDRa }\end{array}$ & Yes & Yes & Yes & Yes \\
\hline IDDRa & 0.4 & 0.8 & 0.2 & 0.6 \\
\hline IDDR & 0.199 & 0.761 & 0.149 & 0.55 \\
\hline $\begin{array}{c}\text { Check if } \\
\text { IDDR } \leq \text { IDDRa }\end{array}$ & Yes & Yes & Yes & Yes \\
\hline
\end{tabular}

Table - VII: System Performance Evaluation regarding IDR \& IDDR for Model 2

\begin{tabular}{|c|c|c|c|c|}
\hline Type & \multicolumn{4}{|c|}{$\begin{array}{c}\text { "' Shaped Open-Bare } \\
\text { Frame }\end{array}$} \\
\hline $\begin{array}{l}\text { Performance } \\
\mathrm{Obj} \text {. }\end{array}$ & \multicolumn{2}{|c|}{$\begin{array}{c}\text { Basic Safety } \\
\text { Obj. }\end{array}$} & \multicolumn{2}{|c|}{$\begin{array}{c}\text { Enhanced } \\
\text { Safety Obj. }\end{array}$} \\
\hline $\begin{array}{c}\text { Seismic } \\
\text { Hazard Level } \\
\end{array}$ & DBE & MCE & DBE & MCE \\
\hline $\begin{array}{l}\text { Optimum } \\
\text { Section } \\
\text { dimensions } \\
\left(\mathrm{mm}^{*} \mathrm{~mm}\right)\end{array}$ & \multicolumn{2}{|c|}{$\begin{array}{c}\text { Col: } \\
(400 \mathrm{X} 400), \\
\text { Beam: } \\
(230 \times 350) \\
\end{array}$} & \multicolumn{2}{|c|}{$\begin{array}{c}\text { Col: } \\
(450 \mathrm{D} 450), \\
\text { Beam: } \\
(230 \mathrm{X} 350) \\
\end{array}$} \\
\hline IDRa & 1.5 & 2.5 & 1 & 2 \\
\hline IDR (\%) & 0.95 & 1.67 & 0.872 & 1.566 \\
\hline $\begin{array}{c}\text { Check if } \\
\text { IDR } \leq \text { IDRa }\end{array}$ & Yes & Yes & Yes & Yes \\
\hline IDDRa & 0.4 & 0.8 & 0.2 & 0.6 \\
\hline IDDR & 0.216 & 0.76 & 0.129 & 0.47 \\
\hline $\begin{array}{c}\text { Check if } \\
\text { IDDR } \leq \text { IDDRa }\end{array}$ & Yes & Yes & Yes & Yes \\
\hline
\end{tabular}

Table - VIII : System Performance Evaluation regarding IDR \& IDDR for Model 3

\begin{tabular}{|c|c|c|c|c|}
\hline Type & \multicolumn{4}{|c|}{$\begin{array}{c}\text { E Shaped Building-Bare } \\
\text { Frame }\end{array}$} \\
\hline $\begin{array}{l}\text { Performance } \\
\text { Obj. }\end{array}$ & \multicolumn{2}{|c|}{$\begin{array}{c}\text { Basic Safety } \\
\mathrm{Obj} .\end{array}$} & \multicolumn{2}{|c|}{$\begin{array}{c}\text { Enhanced } \\
\text { Safety Obj. }\end{array}$} \\
\hline $\begin{array}{c}\text { Seismic } \\
\text { Hazard Level }\end{array}$ & DBE & $\mathrm{MCE}$ & DBE & MCE \\
\hline $\begin{array}{l}\text { Optimum } \\
\text { Section } \\
\text { dimensions } \\
\left(\mathrm{mm}^{*} \mathrm{~mm}\right)\end{array}$ & \multicolumn{2}{|c|}{$\begin{array}{c}\text { Col: } \\
(400 \mathrm{X} 400), \\
\text { Beam: } \\
(230 \mathrm{X} 350)\end{array}$} & \multicolumn{2}{|c|}{$\begin{array}{c}\text { Col: } \\
(450 \mathrm{X} 450), \\
\text { Beam: } \\
(230 \mathrm{X} 350)\end{array}$} \\
\hline IDRa & 1.5 & 2.5 & 1 & 2 \\
\hline IDR-X (\%) & 0.896 & 1.61 & 0.834 & 1.487 \\
\hline IDR-Y $(\%)$ & 0.997 & 1.714 & 0.921 & 1.569 \\
\hline $\begin{array}{l}\text { Check if } \\
\text { IDR } \leq \text { IDRa }\end{array}$ & Yes & Yes & Yes & Yes \\
\hline IDDRa & 0.4 & 0.8 & 0.2 & 0.6 \\
\hline IDDR-X & 0.159 & 0.54 & 0.114 & 0.39 \\
\hline IDDR-Y & 0.199 & 0.72 & 0.128 & 0.45 \\
\hline $\begin{array}{c}\text { Check if } \\
\text { IDDR } \leq \text { IDDRa }\end{array}$ & Yes & Yes & Yes & Yes \\
\hline
\end{tabular}

Table - IX : System Performance Evaluation regarding IDR \& IDDR for Model 4

\begin{tabular}{|c|c|c|c|c|}
\hline Type & \multicolumn{4}{|c|}{$\begin{array}{l}\text { Regular Building-Infilled } \\
\text { Frame }\end{array}$} \\
\hline $\begin{array}{l}\text { Performance } \\
\text { Obj. }\end{array}$ & \multicolumn{2}{|c|}{$\begin{array}{l}\text { Basic Safety } \\
\text { Obj. }\end{array}$} & \multicolumn{2}{|c|}{$\begin{array}{l}\text { Enhanced } \\
\text { Safety Obj. }\end{array}$} \\
\hline $\begin{array}{c}\text { Seismic } \\
\text { Hazard Level }\end{array}$ & DBE & $\mathrm{MCE}$ & DBE & $\mathrm{MCE}$ \\
\hline $\begin{array}{l}\text { Optimum } \\
\text { Section } \\
\text { dimensions } \\
\left(\mathrm{mm}^{*} \mathrm{~mm}\right)\end{array}$ & \multicolumn{2}{|c|}{$\begin{array}{c}\text { Col: } \\
(350 \times 350), \\
\text { Beam: } \\
(230 \times 350)\end{array}$} & \multicolumn{2}{|c|}{$\begin{array}{c}\text { Col: } \\
(350 \times 350), \\
\text { Beam: } \\
(230 \times 350)\end{array}$} \\
\hline IDRa & 1.5 & 2.5 & 1 & 2 \\
\hline IDR (\%) & 0.988 & 1.877 & 0.988 & 1.877 \\
\hline $\begin{array}{c}\text { Check if } \\
\text { IDR } \leq \text { IDRa }\end{array}$ & Yes & Yes & Yes & Yes \\
\hline & & & & \\
\hline IDDRa & 0.4 & 0.8 & 0.2 & 0.6 \\
\hline IDDR & 0.107 & 0.52 & 0.107 & 0.52 \\
\hline $\begin{array}{c}\text { Check if } \\
\text { IDDR } \leq \text { IDDRa }\end{array}$ & Yes & Yes & Yes & Yes \\
\hline
\end{tabular}

Table - X: System Performance Evaluation regarding IDR \& IDDR for Model 5

\begin{tabular}{|c|c|c|c|c|}
\hline Type & \multicolumn{4}{|c|}{$\begin{array}{c}\text { '+ 'Shaped Open-Infilled } \\
\text { Frame }\end{array}$} \\
\hline $\begin{array}{c}\text { Performance } \\
\text { Obj. }\end{array}$ & \multicolumn{2}{|c|}{$\begin{array}{l}\text { Basic Safety } \\
\text { Obj. }\end{array}$} & \multicolumn{2}{|c|}{$\begin{array}{l}\text { Enhanced } \\
\text { Safety Obj. }\end{array}$} \\
\hline $\begin{array}{c}\text { Seismic } \\
\text { Hazard Level }\end{array}$ & DBE & MCE & DBE & MCE \\
\hline $\begin{array}{l}\text { Optimum } \\
\text { Section } \\
\text { dimensions } \\
\left(\mathrm{mm}^{*} \mathrm{~mm}\right)\end{array}$ & \multicolumn{2}{|c|}{$\begin{array}{c}\text { Col: } \\
(400 \mathrm{X} 400), \\
\text { Beam: } \\
(230 \mathrm{X} 350)\end{array}$} & \multicolumn{2}{|c|}{$\begin{array}{c}\text { Col: } \\
(500 \mathrm{X} 500) \text {, } \\
\text { Beam: } \\
(230 \times 350) \\
\end{array}$} \\
\hline IDRa & 1.5 & 2.5 & 1 & 2 \\
\hline IDR (\%) & 0.737 & 1.38 & 0.624 & 1.236 \\
\hline $\begin{array}{c}\text { Check if } \\
\text { IDR } \leq \text { IDRa }\end{array}$ & Yes & Yes & Yes & Yes \\
\hline & & & & \\
\hline IDDRa & 0.4 & 0.8 & 0.2 & 0.6 \\
\hline IDDR & 0.22 & 0.72 & 0.182 & 0.58 \\
\hline $\begin{array}{c}\text { Check if } \\
\text { IDDR } \leq \text { IDDRa }\end{array}$ & Yes & Yes & Yes & Yes \\
\hline
\end{tabular}

Published By:

Blue Eyes Intelligence Engineering

and Sciences Publication

DOI:10.35940/ijeat.B2090.121022

(C) Copyright: All rights reserved.

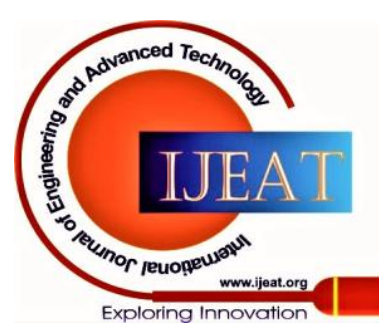


Table - XI: System Performance Evaluation regarding IDR \& IDDR for Model 6

\begin{tabular}{|c|c|c|c|c|}
\hline Type & \multicolumn{4}{|c|}{$\begin{array}{c}\text { E Shaped Building-Infilled } \\
\text { Frame }\end{array}$} \\
\hline $\begin{array}{l}\text { Performance } \\
\mathrm{Obj} \text {. }\end{array}$ & \multicolumn{2}{|c|}{$\begin{array}{c}\text { Basic Safety } \\
\mathrm{Obj} .\end{array}$} & \multicolumn{2}{|c|}{$\begin{array}{c}\text { Enhanced } \\
\text { Safety Obj. }\end{array}$} \\
\hline $\begin{array}{c}\text { Seismic } \\
\text { Hazard Level }\end{array}$ & DBE & $\mathrm{MCE}$ & DBE & MCE \\
\hline $\begin{array}{l}\text { Optimum } \\
\text { Section } \\
\text { dimensions } \\
\left(\mathrm{mm}^{*} \mathrm{~mm}\right)\end{array}$ & \multicolumn{2}{|c|}{$\begin{array}{c}\text { Col: } \\
(400 \mathrm{X} 400), \\
\text { Beam: } \\
(230 \mathrm{X} 350)\end{array}$} & \multicolumn{2}{|c|}{$\begin{array}{c}\text { Col: } \\
(450 \times 450), \\
\text { Beam: } \\
(230 \times 350)\end{array}$} \\
\hline IDRa & 1.5 & 2.5 & 1 & 2 \\
\hline IDR-X $(\%)$ & 0.707 & 1.318 & 0.662 & 1.208 \\
\hline IDR-Y $(\%)$ & 0.82 & 1.463 & 0.748 & 1.34 \\
\hline $\begin{array}{c}\text { Check if } \\
\text { IDR } \leq \text { IDRa }\end{array}$ & Yes & Yes & Yes & Yes \\
\hline IDDRa & 0.4 & 0.8 & 0.2 & 0.6 \\
\hline IDDR-X & 0.249 & 0.789 & 0.177 & 0.582 \\
\hline IDDR-Y & 0.267 & 0.799 & 0.176 & 0.557 \\
\hline $\begin{array}{c}\text { Check if } \\
\text { IDDR } \leq \text { IDDRa }\end{array}$ & Yes & Yes & Yes & Yes \\
\hline
\end{tabular}

The results highlight that when there is discontinuity in the diaphragm the base shear capacity of the building is considerably lowered. Hence, to achieve the same performance objectives, models with opening require higher sections for Columns compared to those of models without openings in diaphragm. The infill walls on the other hand increase the initial stiffness of the structure and reduce its ultimate deformation capacity under lateral loads. The following charts show the comparison of base shear and roof displacements at DBE and MCE hazard levels among all the considered models.

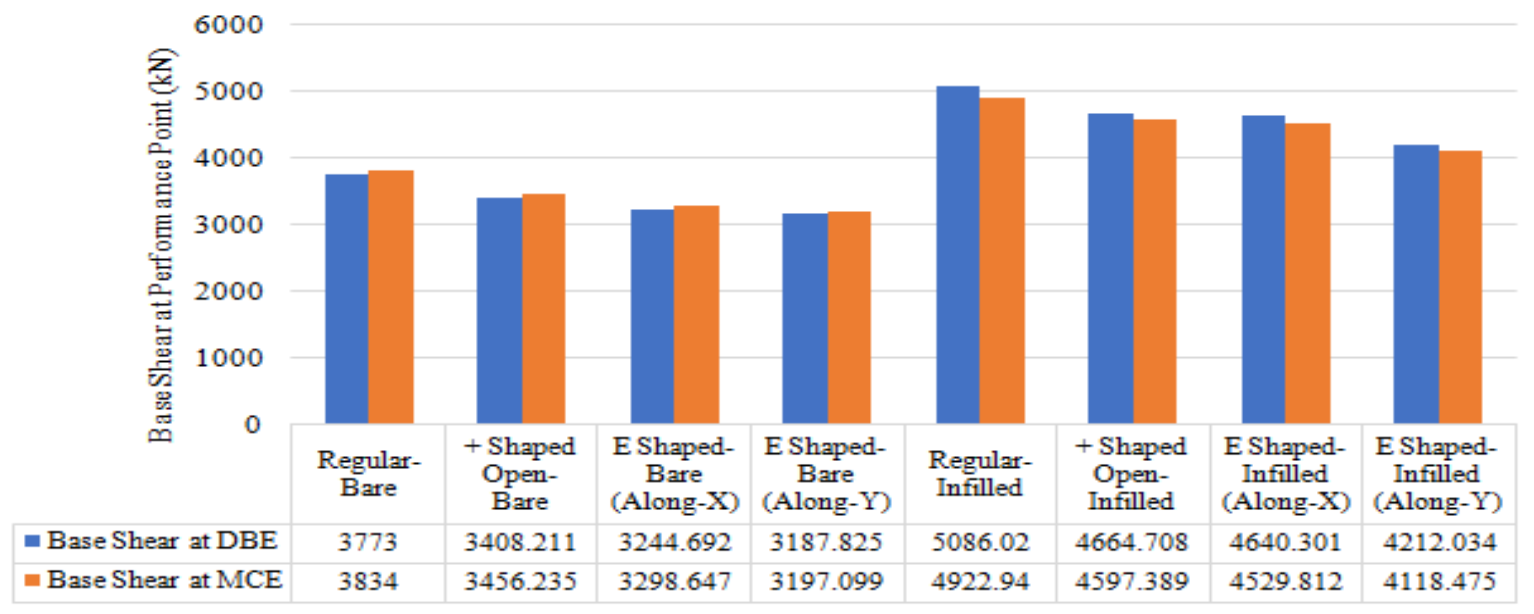

Fig. 8. Base Shear at Performance point for Basic Safety

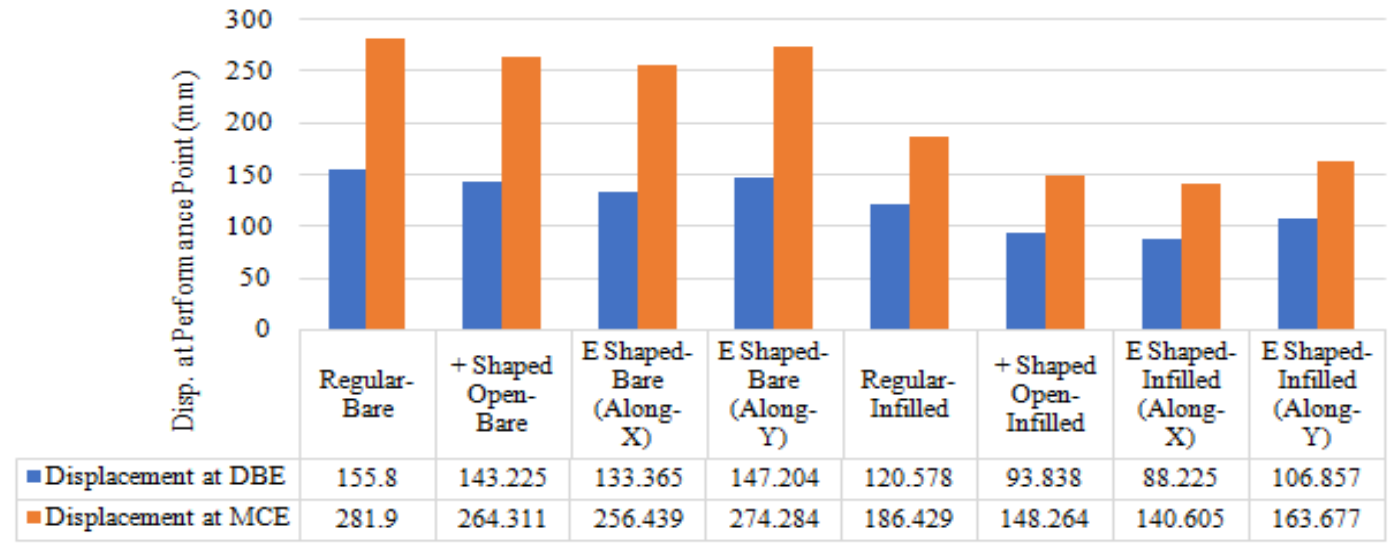

Fig. 9. Displacement at performance point for Basic Safety

Published By:

Blue Eyes Intelligence Engineering and Sciences Publication (C) Copyright: All rights reserved.

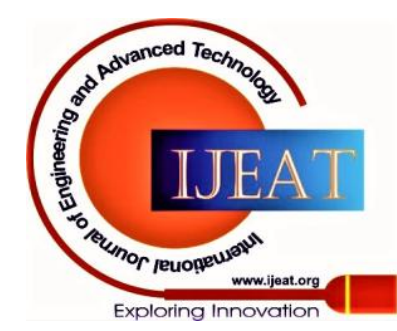




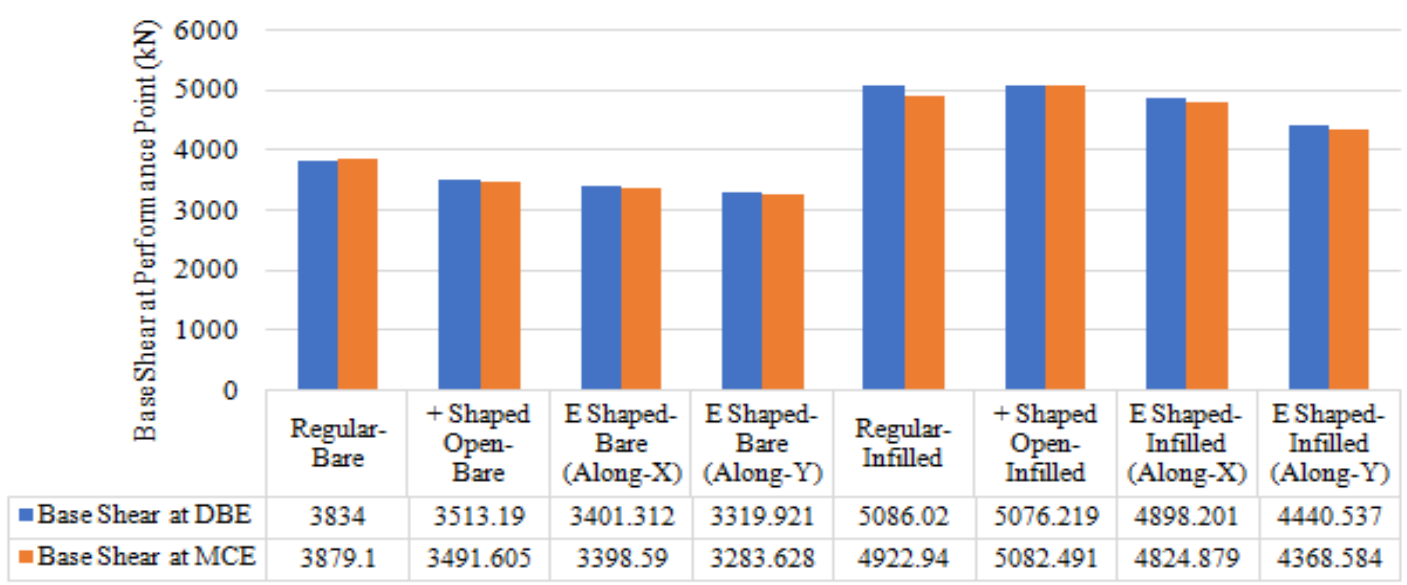

Fig. 10. Base Shear at performance point for Enhanced Safety

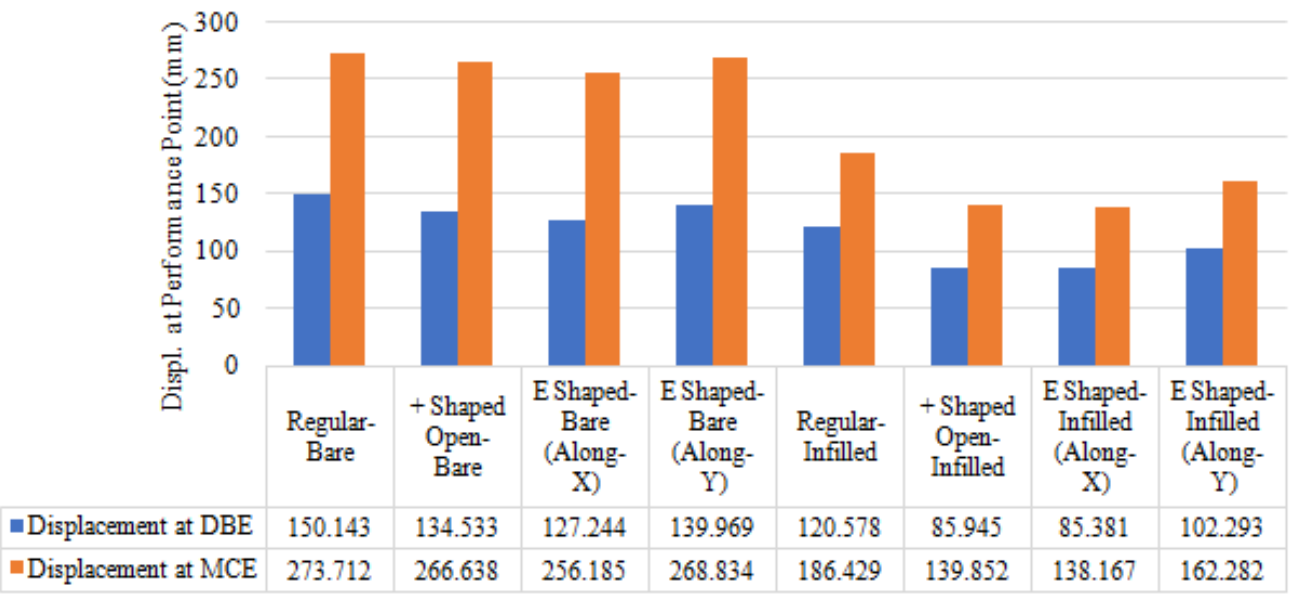

Fig. 11. Displacement at performance point to satisfy the Enhanced Safety

\section{CONCLUSIONS}

Performance based seismic assessment for $(\mathrm{G}+6)$ storeyed infilled buildings with and without diaphragm discontinuity is carried out by pushover analysis. The influence of varying the member dimensions on the performance of the structures was investigated. The following are the salient conclusions that were drawn.

1) Performance of the building improves on increasing the lateral stiffness of column. Thus, byincreasing the beam dimension, the ultimate drift of the pushover curve decreases.

2) Results shows that to obtain the same performance level in terms of parameters IDR and IDDR, higher column size for structural members is required for opening in plan.

3) The base shear capacity and the ultimate displacement reduces in the building with diaphragm discontinuity as compared to the regular building.

4) The pushover curve for models with masonry infills is characterised by high initial stiffness and low deformability. The base shear for all the three models with infills increases by about 30 to 35 percent and the ultimate displacement decreases by 35 to 40 percent as compared to corresponding values for those as bare frame respectively. The infills have an advantageous influence on the Model I while they have an adverse influence on the Model II and Model III due to formation of weak story at ground floor.

5) The hinge formations in bare frame buildings is distributed throughout the structure, whereas in case of buildings with infills the hinges are formed only in several lower stories before the building becomes unstable.

6) The variation in the base shear of the building from performance point at DBE to MCE is very small, whereas the increase in the displacement for the same is very large, which indicates that the buildings behave in non-linear range beyond DBE level of hazard.

\section{REFERENCES}

1. IS-1893-2016 (Part I),“Criteria for Earthquake Resistant Design of Structures" Bureau of Indian Standard , New Delhi.

2. IS - 456:2000, "Indian Standard Code of practice for Plain and Reinforced Concrete", Bureau of Indian Standards, New Delhi

3. IS - 1905 - 1987, "Code of practice for structural use of unreinforced masonry",Bureau of Indian Standards, New Delhi.

4. Applied Technology Council (ATC)-40, "Seismic Evolution and Retrofit of Concrete Building", Report No.SSC 96-01, Volume I, Applied Technology Council, California, November,1996

5. FEMA-356-2000 "Pre-standard and commentary for the seismic rehabilitation of buildings", ASCE for the Federal Emergency Management Agency, Washington D.C.

Published By:

Blue Eyes Intelligence Engineering and Sciences Publication

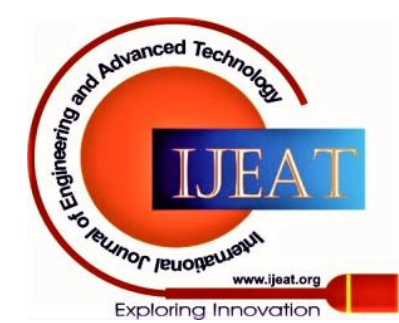


6. FEMA - 440 - 2005 "Improvement of Nonlinear Static Seismic Analysis Procedures" ATC-55 project for Federal Emergency Management Agency, Washington, D.C.

7. SEAOC, "Recommended lateral force requirements and commentary", USA: Structural Engineers Association of California-Seismology Committee: 1999

8. Farzad Naeim, “Seismic Design Handbook,"Los Angeles, California.

9. Matjaz Dolsek, Peter Fajfar (2008, February), "The effect of masonry infills on the seismic response of a four-storey reinforced concrete frame ", Engineering Structures, Available online at www.sciencedirect.com.

\section{AUTHORS PROFILE}

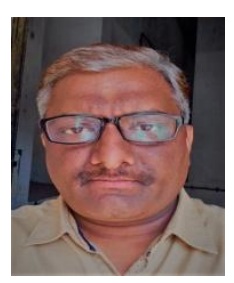

Dr. G. S. Doiphode working as Associate Professor in AppliedMechanics \& Structural Engineering Department. Faculty of Technology \& Engineering, The Maharaja Sayajirao University of Baroda, Vadodara Gujarat-State (India). He have published 30 Research publications in International and national journals and conferences. Hehas total 24 years of teaching experience at UG and PG Level till date.

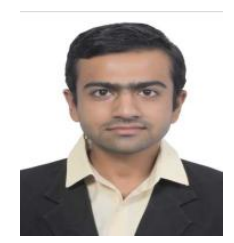

Mr. Vaibhav Dhandhukiya has completed B. E. Civil from Dharmsinh Desai Institute of Technology, Nadiad, Gujarat-State in 2016. He has completed his Master of Structural Engineering at faculty of Technology \& Engineering. The Maharaja Sayajirao University of baroda, Vadodara-Gujrat (India) in July 2018. Presently working as Structural Designer in well known reputed firm of baroda city.

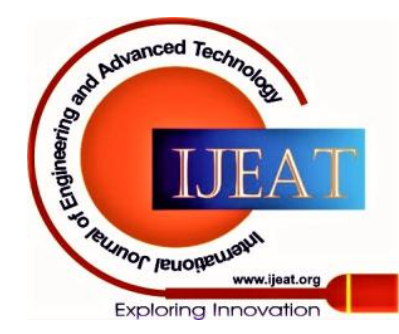

